\title{
Occupational Hand-Related Injuries at a Major Tertiary Care Burn and Reconstructive Center in Pakistan
}

\author{
Dujanah S. Bhatti ${ }^{1}$, Nur U. Ain ${ }^{2}$, Maryam Fatima ${ }^{3}$ \\ 1. Plastic and Reconstructive Surgery, Rawalpindi Medical University, Rawalpindi, PAK 2. Plastic and Reconstructive \\ Department, Holy Family Hospital, Rawalpindi, PAK 3. Burn and Reconstructive Department, Holy Family Hospital, \\ Rawalpindi, PAK
}

Corresponding author: Dujanah S. Bhatti, drdujan@gmail.com

\section{Abstract}

\section{Introduction}

Work-related hand injuries are usually a consequence of mechanical force on hand. This study retrospectively investigated the occurrence of work-related hand injuries in patients belonging to different age groups, gender, educational status, occupation, etc.

\section{Methodology}

This cross-sectional study was conducted from October 2018 to December 2019 at the Department of Burn and Plastic Surgery, Holy Family Hospital, Rawalpindi, Pakistan. Demographic and clinical characteristics were gathered through a structured questionnaire based on relevant literature. Patients were assessed using the purposive sampling technique and written informed consent was taken from each participant. A p-value of $<0.05$ was considered statistically significant. Statistical tests were performed using the Statistical Package for the Social Sciences (SPSS).

\section{Results}

One hundred and twenty participants were interviewed, and $87.5 \%$ of patients did not have a vascular injury, and $62.5 \%$ of patients had an associated fracture. Over half of them (57.5\%) had injuries of their dominant hands. Most of the injuries (67.5\%) involved fingers while the rest of the injuries were found either in the palm or the dorsum of the hand. Among the causes of accidents, the majority didn't wear or wore unfitted gloves (76.6\%) and the main causes of the hand injuries were related to defects in the workplace (53.3\%). Lack of concentration (11.7\%), wearing loose or unfitted clothes or jewelry (19.2\%), lack of machine maintenance (29.2\%), and a patient's chronic disease (1.66\%) were among the less frequent causes.

Received 07/22/2020

Review began $07 / 26 / 2020$ Review ended 09/12/2020 Published 09/14/2020

\section{(c) Copyright 2020}

Bhatti et al. This is an open access article distributed under the terms of the Creative Commons Attribution License CC-BY 4.0., which permits unrestricted use, distribution, and reproduction in any medium, provided the original author and source are credited.

\section{Conclusion}

It is important to understand the relationship between occupational and hand injuries. It provides an insight into the lack of protection and guidance of workers.

Categories: Plastic Surgery, Orthopedics, Trauma

Keywords: burn, occupation, hand injury, fracture

\section{Introduction}

The hand is the most intricate body part consisting of 20 muscles, 27 bones, numerous tendons, and a network of vessels and nerves. It is the most frequently used body part in our various actions; hence, it is the most susceptible to get injured [1]. One of the leading causes of hand injuries is work-related accidents [2]. According to a study conducted in the US, $35.1 \%$ of employees fall victim to work-related injuries [3]. There is a profound burden imposed on the health as well as the socioeconomic status of a person who suffers from such an injury [4]. The loss of productivity that ensues also affects their psychosocial well-being.

An occupational hand injury can vary from simple injuries such as isolated tendon injury to a severely mangled hand [5]. Work-related hand injuries are usually a consequence of mechanical force on hand [6]. The hand can also be subjected to a thermal, chemical, or electrical injury at the workplace. The factors which lead to such injuries include inattention, careless use of machinery/instrument, lack of maintenance of the workplace equipment, lack of personal protective equipment, working overtime, rushing, lack of proper training, etc. [7].

Work-related hand injuries can significantly reduce the quality of life. Studies reveal that with work-related hand injuries, the patient not only loses livelihood, but sometimes it can also cripple the ability to carry out 
daily routine tasks [8]. It was also noted in a study hand injuries create delays in returns to work, adding the financial burden on the patients and their families [9-11].

This study retrospectively investigated the occurrence of work-related hand injuries in patients belonging to different age groups, gender, educational status, occupation, etc. This study also explored various causes that lead to work-related hand injuries and a number of variables that influence such injuries.

\section{Materials And Methods}

This cross-sectional study was conducted from October 2018 to December 2019 at the Department of Burn and Plastic Surgery, Holy Family Hospital, Rawalpindi, Pakistan. The study was approved by the Ethics Review Committee of Rawalpindi Medical University.

The authors developed a structured questionnaire (see appendix) based on relevant literature [12, 13]. The instrument was further pre-tested on 20 patients prior to data collection to assess presentation, acceptability, and ease of understanding of the questions. The questionnaire required little modification prior to use. Patients were assessed using the purposive sampling technique and written informed consent was taken from each participant. Patients were also informed of the study's purpose.

Patients were included in this study only if they were (i) injured at work; (ii) presented in the emergency department; (iii) scheduled for a follow-up visit after one and two weeks from the date of injury; and (iv) had injury limited to hand (including fingers) and wrist zone. The patients under the age of 18 years were only included if they were accompanied by their parents/guardians and were interviewed in the presence of their attendants. However, patients or attendants (in case of a minor patient) who could not provide informed consent were excluded from the study.

Information was collected on the following three sections:

i) Demographic information and other factors: patients were asked to describe their age, gender, education, occupation type, means of transport, and smoking status.

ii) Clinical characteristics: patients were either asked or confirmed through their medical history regarding the type of injury (vascular, nerve), fracture on X-ray, event by exposure, the affected hand is either dominant or non-dominant, type of injury, injuries involved hand, digits involved in hand injuries, time of presentation and place of first aid.

iii) Patients were asked to confirm what are the causes of occupational injuries.

Descriptive statistics were calculated using frequencies and percentages. A Chi-square test was used to assess the association between socio-demographics and clinical characteristics of patients. A p-value of $<0.05$ was considered statistically significant. Statistical tests were performed using the Statistical Package for Social Sciences (SPSS version 26.0; IBM Inc., Armonk, US).

\section{Results}

A total of 120 participants were interviewed. About half (47.5\%) of the participants were less than 18 years of age. About $25 \%$ of patients fell in the age group ranging from 18 years to 35 years, and $15 \%$ belonged to the age group ranging from 35 years to 50 years old. Only $12.5 \%$ were 50 years of age or above. Most of the study participants were male (82.5\%). Over half of the participants were non-skilled workers (52.5\%) and were illiterate (62.5\%). Most of the study participants (52.5\%) were smokers; more than half (30\%) of them smoked more than 20 packs per day (Table 1). 


\section{Cureus}

\begin{tabular}{|c|c|c|c|}
\hline \multicolumn{2}{|l|}{ Description } & Frequency & Percentages \\
\hline \multirow{4}{*}{ Age } & 14 years -18 years & 57 & 47.5 \\
\hline & 18 years -35 years & 30 & 25.0 \\
\hline & 35 years -50 years & 18 & 15.0 \\
\hline & $>50$ years & 15 & 12.5 \\
\hline \multirow{2}{*}{ Gender } & Male & 99 & 82.5 \\
\hline & Female & 21 & 17.5 \\
\hline \multirow{2}{*}{ Patient education } & Illiterate & 75 & 62.5 \\
\hline & Literate & 45 & 37.5 \\
\hline \multirow{3}{*}{ Patient occupation } & Professional & 27 & 22.5 \\
\hline & Skilled & 30 & 25.0 \\
\hline & Non-skilled & 63 & 52.5 \\
\hline \multirow{4}{*}{ Means of transport } & Private car & 21 & 17.5 \\
\hline & Taxi/cab & 36 & 30.0 \\
\hline & On foot & 51 & 42.5 \\
\hline & Ambulance & 12 & 10.0 \\
\hline \multirow{3}{*}{ Smoking status } & Non-smoker & 57 & 47.5 \\
\hline & Smoker $>20$ per day & 36 & 30.0 \\
\hline & Smoker $<20$ per day & 27 & 22.5 \\
\hline
\end{tabular}

TABLE 1: Sociodemographics and smoking status of patients $(n=120)$

We compared patients aged below 50 with those above 50 as the former group consists of patients that are most active and lack comorbidities while the latter group comprises individuals that are less active and might be suffering from certain comorbidities. It was observed that patients aged 50 and below suffered an injury in their dominant hand, had isolated hand injury, and the cause was mostly related to the use of a machine or a tool. They also had evidence of fractures on X-rays. Other causes for males in addition to the use of machinery included interpersonal violence etc. For females and illiterate patients, an isolated, non-dominant hand was found to be involved in injury with evidence of fracture on X-rays, mostly due to the use of machines or tools. Vascular and nerve injury, if present, was more prevalent in female patients. Literate patients suffered from an isolated hand injury in the dominant hand, and causes were other than the use of machines or tools. Skilled and semi-skilled workers tended to have isolated injuries in the dominant hand, while unskilled workers most affected hand was non-dominant. Moreover, unskilled laborers tended to suffer from vascular injury and had radiological evidence of fracture (Table 2 ).

\begin{tabular}{|c|c|c|c|c|c|c|c|c|c|c|}
\hline \multirow{2}{*}{$\begin{array}{l}\text { Demographic } \\
\text { characteristics }\end{array}$} & \multirow[t]{2}{*}{$\mathbf{N}$} & $\begin{array}{l}\text { No n } \\
\text { (\%) }\end{array}$ & $\begin{array}{l}\text { Yes } \\
\text { n (\%) }\end{array}$ & $\begin{array}{l}\mathrm{p}- \\
\text { value }\end{array}$ & No $n(\%)$ & Yes n (\%) & $\begin{array}{l}\mathrm{p}- \\
\text { value }\end{array}$ & No $n(\%)$ & Yes n (\%) & $\begin{array}{l}p- \\
\text { value }\end{array}$ \\
\hline & & \multicolumn{3}{|c|}{ Vascular injury } & \multicolumn{3}{|c|}{ Nerve injury } & \multicolumn{3}{|c|}{ Fracture on X-ray } \\
\hline \multicolumn{11}{|l|}{ Age } \\
\hline 50 and below & 105 & $\begin{array}{l}90 \\
(75.0)\end{array}$ & $\begin{array}{l}15 \\
(12.5)\end{array}$ & & $87(72.5)$ & $18(15.0)$ & \multirow{2}{*}{0.074} & $30(25.0)$ & $75(62.5)$ & \multirow{2}{*}{0.001} \\
\hline Above 50 & 15 & $\begin{array}{l}15 \\
(12.5)\end{array}$ & $\begin{array}{l}0 \\
(0.0)\end{array}$ & & $15(12.5)$ & $0(0.0)$ & & $15(12.5)$ & $0(0.0)$ & \\
\hline \multicolumn{11}{|l|}{ Gender } \\
\hline Male & 99 & 99 & 0 & & 99 (82.5) & $0(0.0)$ & & 21 (17.5) & $54(45.0)$ & \\
\hline
\end{tabular}




\section{Cureus}

\begin{tabular}{|c|c|c|c|c|c|c|c|c|c|c|}
\hline \multirow[b]{2}{*}{ Female } & \multirow[b]{2}{*}{21} & \multirow{2}{*}{$\begin{array}{l}(82.5) \\
6 \\
(5.00)\end{array}$} & \multirow{2}{*}{$\begin{array}{l}(0.0) \\
15 \\
(12.5)\end{array}$} & \multirow{2}{*}{0.001} & \multirow[b]{2}{*}{$3(2.5)$} & \multirow[b]{2}{*}{$18(15.0)$} & \multirow[t]{2}{*}{0.001} & \multirow[b]{2}{*}{$0(0.0)$} & \multirow[b]{2}{*}{$45(37.5)$} & \multirow[t]{2}{*}{0.001} \\
\hline & & & & & & & & & & \\
\hline \multicolumn{11}{|l|}{ Education } \\
\hline Illiterate & 75 & $\begin{array}{l}60 \\
(50.0)\end{array}$ & $\begin{array}{l}15 \\
(12.5)\end{array}$ & \multirow[b]{2}{*}{0.001} & $57(47.5)$ & $18(15.0)$ & \multirow[b]{2}{*}{0.001} & $0(0.0)$ & $75(62.5)$ & \multirow[b]{2}{*}{0.001} \\
\hline Literate & 45 & $\begin{array}{l}45 \\
(37.5)\end{array}$ & $\begin{array}{l}0 \\
(0.0)\end{array}$ & & $45(37.5)$ & $0(0.0)$ & & $45(37.5)$ & $0(0.0)$ & \\
\hline \multicolumn{11}{|c|}{ Patient occupation } \\
\hline $\begin{array}{l}\text { Skilled/semi- } \\
\text { skilled }\end{array}$ & 57 & $\begin{array}{l}57 \\
(47.5)\end{array}$ & $\begin{array}{l}0 \\
(0.0)\end{array}$ & \multirow[b]{2}{*}{0.001} & $57(47.5)$ & $0(0.0)$ & \multirow[b]{2}{*}{0.001} & $45(37.5)$ & $12(10.0)$ & \multirow[b]{2}{*}{0.001} \\
\hline Unskilled labor & 63 & $\begin{array}{l}48 \\
(40.0)\end{array}$ & $\begin{array}{l}15 \\
(12.5)\end{array}$ & & $45(37.5)$ & $18(15.0)$ & & $0(0.0)$ & $63(52.5)$ & \\
\hline \multirow{2}{*}{$\begin{array}{l}\text { Demographic } \\
\text { characteristics }\end{array}$} & \multirow[t]{2}{*}{$\mathrm{N}$} & $\begin{array}{l}\text { No n } \\
\text { (\%) }\end{array}$ & $\begin{array}{l}\text { Yes n } \\
(\%)\end{array}$ & $\begin{array}{l}\mathrm{p}- \\
\text { value }\end{array}$ & $\begin{array}{l}\text { By use of } \\
\text { machine/ tool n } \\
\text { (\%) }\end{array}$ & $\begin{array}{l}\text { Other accidental/ } \\
\text { interpersonal violence n } \\
\text { (\%) }\end{array}$ & $\begin{array}{l}\mathrm{p}- \\
\text { value }\end{array}$ & $\begin{array}{l}\text { Isolated } \\
\text { hand n (\%) }\end{array}$ & $\begin{array}{l}\text { Associated } \\
\text { injury n (\%) }\end{array}$ & $\begin{array}{l}\mathrm{p}- \\
\text { value }\end{array}$ \\
\hline & & $\begin{array}{l}\text { Affected } \\
\text { dominan }\end{array}$ & hand is & & \multicolumn{3}{|l|}{ Event by exposure } & \multicolumn{2}{|c|}{ Type of injury } & \\
\hline \multicolumn{11}{|l|}{ Age } \\
\hline 50 and below & 105 & $\begin{array}{l}36 \\
(30.0)\end{array}$ & $\begin{array}{l}69 \\
(57.5)\end{array}$ & \multirow{2}{*}{0.001} & $66(55.0)$ & $39(32.5)$ & \multirow{2}{*}{0.001} & $105(87.5)$ & $0(0.0)$ & \multirow{2}{*}{0.001} \\
\hline Above 50 & 15 & $\begin{array}{l}15 \\
(12.5)\end{array}$ & $\begin{array}{l}0 \\
(0.0)\end{array}$ & & $0(0.0)$ & $15(12.5)$ & & $6(5.0)$ & $9(7.5)$ & \\
\hline \multicolumn{11}{|l|}{ Gender } \\
\hline Male & 99 & $\begin{array}{l}51 \\
(42.50)\end{array}$ & $\begin{array}{l}48 \\
(40.0)\end{array}$ & \multirow[b]{2}{*}{0.001} & $45(37.5)$ & $54(45.0)$ & \multirow[b]{2}{*}{$0.001^{\star}$} & $90(75.0)$ & $9(7.5)$ & \multirow{3}{*}{0.166} \\
\hline Female & 21 & $0(0.0)$ & $\begin{array}{l}21 \\
(17.5)\end{array}$ & & $21(17.5)$ & $0(0.00)$ & & $21(17.5)$ & $0(0.0)$ & \\
\hline \multicolumn{10}{|l|}{ Education } & \\
\hline Illiterate & 75 & $6(5.0)$ & $\begin{array}{l}69 \\
(57.5)\end{array}$ & \multirow{2}{*}{0.001} & $66(55.0)$ & $9(7.5)$ & 0.001 & 75 (62.5) & $0(0.0)$ & 0.001 \\
\hline Literate & 45 & $\begin{array}{l}45 \\
(37.5)\end{array}$ & $\begin{array}{l}0 \\
(0.0)\end{array}$ & & $0(0.0)$ & $45(37.5)$ & & $36(30.0)$ & $9(7.5)$ & \\
\hline Patient occupat & & & & & & & & & & \\
\hline $\begin{array}{l}\text { Skilled/semi- } \\
\text { skilled }\end{array}$ & 57 & $\begin{array}{l}51 \\
(42.5)\end{array}$ & $\begin{array}{l}6 \\
(5.0)\end{array}$ & & $3(2.5)$ & $54(45.0)$ & & $48(40.0)$ & $9(7.5)$ & \\
\hline Unskilled labor & 63 & $0(0.0)$ & $\begin{array}{l}63 \\
(52.5)\end{array}$ & 0.001 & $63(52.5)$ & $0(0.0)$ & 0.001 & $63(52.5)$ & $0(0.0)$ & 0.01 \\
\hline
\end{tabular}

TABLE 2: Association between socio-demographics and clinical characteristics of patients 


\section{Cureus}

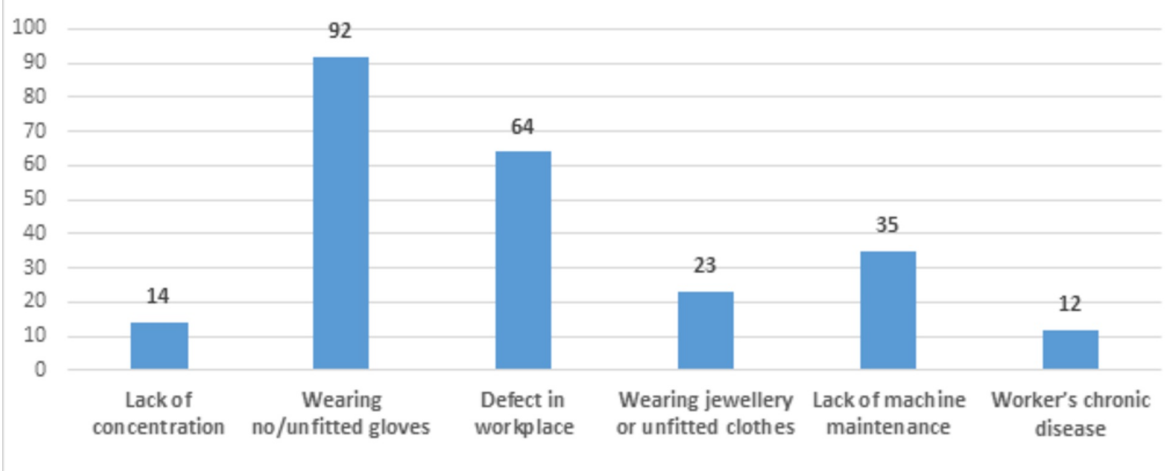

FIGURE 1: Cause of occupational injury $(n=120)$

Over half of the study subjects (57.5\%) were injured in their dominant hands. Fifty-one percent of patients presented to the emergency room on foot, followed by taxi and private cars. Over half of the participants (55\%) were using machinery or tools during the injury. Patients facing injury due to accidents such as falls were $33.5 \%$, while $12.5 \%$ of injuries were attributed to interpersonal violence. About $65 \%$ of the study population presented from $2 \mathrm{pm}$ to $10 \mathrm{pm}$. A minority (7.5\%) presented overnight. Less than half of the participants (35\%) received first aid measures after the injury, and more than half of them (63.3\%) reached the hospital by taxi (Table 3). 


\section{Cureus}

\begin{tabular}{|c|c|c|c|}
\hline \multicolumn{2}{|l|}{ Description } & Frequency & Percentages \\
\hline \multirow{2}{*}{ Vascular injury } & Yes & 15 & 12.5 \\
\hline & No & 105 & 87.5 \\
\hline \multirow{2}{*}{ Nerve injury } & Yes & 18 & 15.0 \\
\hline & No & 102 & 85.0 \\
\hline \multirow{2}{*}{ Fracture on X-ray } & Yes & 75 & 62.5 \\
\hline & No & 45 & 37.5 \\
\hline \multirow{3}{*}{ Event by exposure } & By use of machine/tool & 66 & 55.0 \\
\hline & Other accidental (e.g., fall) & 39 & 32.5 \\
\hline & Interpersonal violence & 15 & 12.5 \\
\hline \multirow{2}{*}{ Affected hand } & Dominant & 69 & 57.5 \\
\hline & Non-dominant & 51 & 42.5 \\
\hline \multirow{2}{*}{ Type of injury } & Isolated hand injury & 111 & 92.5 \\
\hline & Associated injury & 9 & 7.5 \\
\hline \multirow{3}{*}{ Injuries involving hand } & Finger & 81 & 67.5 \\
\hline & Palm & 24 & 20 \\
\hline & Dorsum & 27 & 22.5 \\
\hline \multirow{5}{*}{ Digits involved in hand injuries } & Little & 12.0 & 10.0 \\
\hline & Ring & 42.0 & 35.0 \\
\hline & Middle & 36.0 & 30.0 \\
\hline & Index & 54.0 & 45.0 \\
\hline & Thumb & 33.0 & 27.5 \\
\hline \multirow{3}{*}{ Time of presentation } & $8 \mathrm{am}-2 \mathrm{pm}$ & 33 & 27.5 \\
\hline & $2 p m-10 p m$ & 78 & 65.0 \\
\hline & 10 pm - 8 am & 9 & 7.5 \\
\hline \multirow{2}{*}{ Place of first aid } & At the workplace & 42 & 35.0 \\
\hline & Outside workplace & 78 & 65.0 \\
\hline
\end{tabular}

TABLE 3: Clinical information of patients $(n=120)$

Most of the injuries (67.5\%) involved fingers, while the rest of the injuries were found either in the palm or the dorsum of the hand. The little finger was least commonly (10\%) involved in the injuries, while the index finger was most commonly involved (45\%). The incidence of the involvement of the rest of the digits was almost equal, i.e., ring finger (35\%), middle finger (30\%), and thumb (27.5\%). In $62.5 \%$ of workplace hand injuries, there was radiographic evidence of fracture. Most of the patients did not have any vascular (87.5\%) or nerve (85\%) injury.

\section{Discussion}

The patient presenting with hand injuries can serve as clinical data on occupation incurred trauma and a surveillance tool to identify the likelihood of job categories and the related incidence of injuries. It also elucidates the most noticeable category of injury, along with its associated fractures and neurovascular damage. In our study, the majority (47.5\%) of the patients presenting in our outpatient clinic or the emergency department were under the age of 18 years. The elderly population had an exceedingly small fraction to present in our study. These figures were consistent with a study done by Smith et al. in which the largest pool of patients was the younger age group (less than 18 years of age) [14]. This could be because, in 
our region, child-driven labor is widely practiced, despite restrictions [15]. The younger population also lacks the proper skills and training to handle equipment that is associated with a higher risk of occupational injuries. Warner et al. showed similar results - younger patients were prevalent [16]. The older age group, i.e., 50 years and more, have decreased ability to take part in occupational activities, and most of them retire by the age of 60 years; hence this age group showed less incidence of occupation-related hand injuries [17]. Gender distribution has a higher ratio of male to female in our sample. This is similar to other studies where males were given more manual-intense labor [18]; this could attribute to the greater male population in our study. We observed a gender variance with the male predominance of occupation-related hand injuries, which corroborates with the study by Farhad et al. [19]. The dominance of the male gender can be due to the cultural and social norms of our country where the male is the bread earner of the family, and financial aspects of the household are the responsibility of the male. Therefore, males have a much higher employment rate than women and thus are more prone to getting occupation-related hand injuries.

Concerning the literacy status of our participants, Illiterate and non-skilled individuals made most of our patients. This was consistent with a study done by Shankar et al. in which a significant proportion of injured patients were of the same category ( $41.3 \%$ illiterate and $41.5 \%$ non-skilled) [20]. This suggested that the educational status of individuals has a direct correlation with occupation-related hand injuries. Illiterate and non-skilled workers were not familiar with safe practices, which makes them susceptible to workrelated hand injuries. Our study involved occupations that involved labor-intense manual work that included handy work and operation of heavy machinery. These occupations are vulnerable to injuries such as lacerations, de-gloving injury, fractures, neurovascular compromise, amputation, etc. Singh et al. showed similar results in India [21].

Means of transportation are noteworthy because if the patient reached the hospital by ambulance, one must have received first aid. Contrary to this, there is a time delay which suspends the receiving of the first aid if the patient has used personal transport. Undue delays can be encountered if one takes a cab; however, if the patient uses personal transportation, reaching the hospital happens without such delays.

Occupational injuries without major vascular and nerve injuries were common in our study. Ninety-two percent of the injured in the studied population had isolated hand injuries. Injuries to nerves only accounted for $18 \%$ of the studied population. Similarly, vascular damage was seen in $15 \%$. Lack of proper training in assessment of cutaneous nerve distribution and vascular assessment at the time of initial patient assessment could attribute to missed nerve and vascular injuries. This could be the reason why our study detected only $15 \%$ documented nerve damages on presentation. Similar aspects of nerve involvement were seen by a study done by Strong et al. in which definitive diagnostic nerve conduction study had to be employed to find out the exact quantification of the true incidence of peripheral neuropathy. The most frequent non-cutaneous injury documented in our study were bone fractures, accounting for $62 \%$. This could be attributed to the early recognition of fracture on an X-ray or clinical examination. Fracture is more evident in the primary survey and hence rarely missed [22].

The type and intensity of occupation play a major role in occupation-related hand injuries and can be deadly at times. We observed that machine work and the use of hand tools resulted in a little more than half of the work-related hand injuries. These figures are similar to Hunt et al. findings, where they compared fatal and non-fatal workplace injures [23]. Hand lateralization was seen in 69\% in our results, like Arifi et al., where involvement of the dominant hand was almost 50\%. The resulting negative impact on the vocational and economic status of the patient can lead to anxiety and distress [24]. Sixty-five percent of the patients presented to the medical institution during the afternoon. This could be because the working hours in our region and late presentation could be due to lack of transport availability as most of our patients utilized private cars or preferred walking to the hospital due to lack of any other source of conveyance (42\%).

It is estimated that fingers are mostly affected by accounting for $67 \%$ of total injuries. Injuries of the hand could be predominant in our population because of male dominance and accidents attained during work involving hand-work. This is supported by Abu-Sittah el al., who showed that injuries to fingers prevailing palm injuries [25]. We also saw that index and ring fingers were commonly affected. These injuries should be immediately taken care of as they can result in grave consequences impacting the functional status of the patient and hence economic and psychosocial well-being.

It is observed that most of the laborers are smokers, and their engagement in smoking activities while working can lead to distraction and ultimately result in work-related injuries. This is aggravated by the lack of usage of personal protective equipment such as gloves etc. Not wearing gloves or wearing unfitted gloves was found to be the primary cause of occupation-related hand injuries, which contradicts the results of the study done by Jin et al. [26]. Defects in the workplace and lack of machine maintenance were other common causes being supported by findings of other studies [27] but contradict the study conducted by Mostafa et al., where the lack of concentration was found to be a less common cause of work-related hand injuries [28].

\section{Conclusions}

It is important to understand the relationship between occupational activities and hand injuries. It provides an insight into the lack of protection and guidance for workers involved in professions that apply hand- 
work. It also provides us with a better understanding of the management of such injuries. Documented risk factors can be considered to prevent such occupational injuries in the future.

\section{Appendices}

\section{Questionnaire}

I volunteer to take part in occupational injuries study questionnaire. I understand that the research aims to collect data from me. The data collected in this questionnaire will be used in study conducted by Burn and Reconstructive surgery center Rawalpindi. I have understood that all data provided will be treated in strict confidence, and that my name and organization will be anonymized. I have read and understood the explanation of the research project provided to me. I have had the opportunity to ask any questions and they have been answered to my satisfaction.

\begin{tabular}{|c|c|c|c|c|c|c|}
\hline Variables & \multicolumn{6}{|c|}{ PLEASE SLEECT ONE or MORE OF THE FOLLOWING } \\
\hline Age in years & & & & & & \\
\hline Gender & \multicolumn{3}{|c|}{ Male } & \multicolumn{3}{|c|}{ female } \\
\hline Education & \multicolumn{3}{|c|}{ literate } & \multicolumn{3}{|c|}{ Illiterate } \\
\hline Occupation & \multicolumn{3}{|c|}{ Professional } & Skilled & \multicolumn{2}{|c|}{ Nonskilled } \\
\hline $\begin{array}{l}\text { Means of } \\
\text { transport }\end{array}$ & Private & \multicolumn{2}{|c|}{ Taxi, cab } & \begin{tabular}{c|} 
On \\
foot
\end{tabular} & \multicolumn{2}{|c|}{ ambulance } \\
\hline Smoking status & Nonsmoker & \multicolumn{2}{|c|}{$\begin{array}{c}\text { Smokes }<20 \text { cigarettes } \\
\text { per day }\end{array}$} & \multicolumn{3}{|c|}{ Smokes $<20$ cigarette per day } \\
\hline Hand affected & Dominant & \multicolumn{5}{|c|}{ Non-dominant } \\
\hline $\begin{array}{l}\text { Injury involving } \\
\text { hand }\end{array}$ & Finger & \multicolumn{2}{|c|}{ Palm } & \multicolumn{3}{|c|}{ Dorsum } \\
\hline Digit involved & Little & \multicolumn{2}{|c|}{ Ring } & Middle & Index & thumb \\
\hline $\begin{array}{c}\text { Time of } \\
\text { presentation }\end{array}$ & $8 \mathrm{am}-2 \mathrm{pm}$ & \multicolumn{2}{|c|}{$2 \mathrm{pm}-10 \mathrm{pm}$} & \multicolumn{3}{|c|}{$10 p m-8 a m$} \\
\hline First aid & At workplace & \multicolumn{5}{|c|}{ Outside workplace (open area) not enclosed within the building } \\
\hline $\begin{array}{l}\text { Event by } \\
\text { Exposure }\end{array}$ & $\begin{array}{c}\text { By use of } \\
\text { machine/ took }\end{array}$ & \multicolumn{2}{|c|}{$\begin{array}{l}\text { Other accidental (e.g. } \\
\text { Fall) }\end{array}$} & \multicolumn{3}{|c|}{ Interpersonal violence } \\
\hline Type of injury & $\begin{array}{l}\text { Isolated hand } \\
\text { injury }\end{array}$ & \multicolumn{5}{|c|}{ Associated injuries } \\
\hline \multirow{2}{*}{$\begin{array}{l}\text { Associated } \\
\text { injuries }\end{array}$} & Vascular Injury & \multicolumn{2}{|c|}{ Yes } & \multicolumn{3}{|c|}{ No } \\
\hline & Nerve injury & \multicolumn{2}{|c|}{ Yes } & \multicolumn{3}{|c|}{ No } \\
\hline $\begin{array}{l}\text { Radiological } \\
\text { evidence of } \\
\text { fracture }\end{array}$ & Yes & \multicolumn{5}{|c|}{ No } \\
\hline $\begin{array}{l}\text { Cause of } \\
\text { Occupational } \\
\text { injury }\end{array}$ & $\begin{array}{c}\text { Lack of } \\
\text { concentration }\end{array}$ & $\begin{array}{l}\text { Wearing } \\
\text { no/unfitted } \\
\text { gloves }\end{array}$ & $\begin{array}{l}\text { Defect in } \\
\text { workplace }\end{array}$ & $\begin{array}{c}\text { Wearing } \\
\text { jewelry or } \\
\text { unfitted } \\
\text { clothes }\end{array}$ & $\begin{array}{c}\text { Lack of } \\
\text { machine } \\
\text { maintenanc } \\
\text { e }\end{array}$ & $\begin{array}{l}\text { Workers } \\
\text { chronic } \\
\text { disease }\end{array}$ \\
\hline
\end{tabular}

FIGURE 2: Questionnaire

\section{Additional Information}

\section{Disclosures}

Human subjects: Consent was obtained by all participants in this study. Rawalpindi Medical University Ethical Review Board issued approval 59/IREF/RMU/2020. Animal subjects: All authors have confirmed that this study did not involve animal subjects or tissue. Conflicts of interest: In compliance with the ICMJE uniform disclosure form, all authors declare the following: Payment/services info: All authors have declared that no financial support was received from any organization for the submitted work. Financial relationships: All authors have declared that they have no financial relationships at present or within the previous three years with any organizations that might have an interest in the submitted work. Other relationships: All authors have declared that there are no other relationships or activities that could appear to have influenced the submitted work.

\section{References}

1. Abebe MW: Common causes and types of hand injuries and their pattern of occurrence in Yekatit 12 
Hospital, Addis Ababa, Ethiopia. Pan Afr Med J. 2019, 33:142. 10.11604/pamj.2019.33.142.18390

2. Trybus M, Lorkowski J, Brongel L, Hladki W: Causes and consequences of hand injuries . Am J Surg. 2006, 192:52-57. 10.1016/j.amjsurg.2005.10.055

3. Free H, Groenewold MR, Luckhaupt SE: Lifetime prevalence of self-reported work-related health problems among U.S. workers - United States. Morb Mortal Wkly Rep. 2020, 69:361-365. 10.15585/mmwr.mm6913a1

4. Rosberg HE, Carlsson KS, Cederlund RI, Ramel E, Dahlin LB: Costs and outcome for serious hand and arm injuries during the first year after trauma - a prospective study. BMC Public Health. 2013, 24:501. 10.1186/1471-2458-13-501

5. Ihekire O, Salawu SA, Opadele T: International surgery: causes of hand injuries in a developing country . Can J Surg. 2010, 53:161-166.

6. Injury surveillance: a tool for decision-making: annual injury surveillance report, Egypt, 2009 . (2010). https://apps.who.int/iris/handle/10665/116634.

7. Chow CY, Lee H, Lau J, Yu IT: Transient risk factors for acute traumatic hand injuries: a case-crossover study in Hong Kong. Occup Environ Med. 2007, 64:47-52. 10.1136/oem.2006.028589

8. Gustafsson M, Ahlström G: Problems experienced during the first year of an acute traumatic hand injury - a prospective study. J Clin Nurs. 2004, 13:986-995. https://doi.org/10.1111/j.1365-2702.2004.01019.x

9. Eisele A, Dereskewitz C, Kus S, Oberhauser C, Rudolf K-D, Coenen M: Factors affecting time off work in patients with traumatic hand injuries - a bio-psycho-social perspective. Injury. 2018, 49:1822-1829. https://doi.org/10.1016/j.injury.2018.07.012

10. Opsteegh L, Reinders-Messelink HA, Schollier D, et al.: Determinants of return to work in patients with hand disorders and hand injuries. J Occup Rehabil. 2009, 19:245-255. 10.1007/s10926-009-9181-4

11. Russell RC, Bulstrode CJ, Williams NS: Bailey \& Love's Short Practice of Surgery, 24th edition . Hodder Arnold Publication, 2004.

12. Reichard AA, Konda S, Jackson LL: Occupational burns treated in emergency departments. Am J Ind Med. 2015, 58:290-298. 10.1002/ajim.22407

13. Martins C, Echevarría-Guanilo M, Silveira D, Gonzales R, Pai D: Risk perception of work-related burn injuries from the workers perspective. Texto Contexto Enferm. 2015, 24:1148-1156. 10.1590/01040707201500000880015

14. Smith G, Wellman HM, Sorock GS, et al.: Injuries at work in the US adult population: contributions to the total injury burden. Am J Public Health. 2005, 95:1213-1219. 10.2105/AJPH.2004.049338

15. Nafees AA, Khan KS, Fatmi Z, Aslam M: Situation analysis of child labour in Karachi, Pakistan: a qualitative study. J Pak Med Assoc. 2012, 62:1075-1082.

16. Warner M, Barnes PM, Fingerhut LA: Injury and poisoning episodes and conditions: National Health Interview Survey, 1997. Vital and health statistics. Series 10, Data from the National Health Survey. Centers for Disease Control and PreventionNational Center for Health Statistics, Maryland; 2000.

17. Fraade-Blanar LA, Sears JM, Chan KC, Thompson HJ, Crane PK, Ebel BE: Relating Older Workers' Injuries to the Mismatch Between Physical Ability and Job Demands. J Occup Environ Med. 2017, 59:212-221. 10.1097/JOM.0000000000000941

18. Azaroff L, Levenstein C, Wegman DH: Occupational injury and illness surveillance: conceptual filters explain underreporting. Am J Public Health. 2002, 92:1421-1429. 10.2105/ajph.92.9.1421

19. Ali F, Zeb S, Ullah N, et al.: PW 0062 Hand injuries and its associated factors: a cross sectional study among industrial workers at hayatabad, peshawar. Inj Prev. 2018, 24:A208. 10.1136/injuryprevention-2018safety. 576

20. Shankar G, Naik V: A study of residual physical disability after a burn injury in patients admitted in tertiary care hospitals in Karnataka, India. Indian J Burns. 2016, 24:58. 10.4103/0971-653X.195528

21. Singh MV, Ganguli SK, Aiyanna BM, Singh MV, Ganguli SK, Aiyanna BM: A study of epidemiological aspects of burn. Med J Armed Forces India. 1996, 52:229-232. 10.1016/S0377-1237(17)30872-9

22. Strong A, Agarwal S, Cederna P, Levi B: Peripheral neuropathy and nerve compression syndromes in burns . Clin Plast Surg. 2017, 44:793-803. 10.1016/j.cps.2017.05.010

23. Hunt J, Calvert C, Peck M, Meyer A: Occupation-related burn injuries. J Burn Care Reh. 2000, 21:327-332. 10.1067/mbc.2000.108092

24. Arifi HM, Duci SB, Zatriqi VK, et al.: A retrospective study of 572 patients with hand burns treated at the Department of Plastic Surgery Kosovo during the period 2000-2010. Int J Burns Trauma. 2014:7-13.

25. Abu-Sittah GS, El Khatib AM, Dibo SA: Thermal injury to the hand: review of the literature. Ann Burns Fire Disasters. 2011, 24:175-185.

26. Jin K, Lombardi DA, Courtney TK, et al.: A case-crossover study of work-related acute traumatic hand injuries in the People's Republic of China. Scand J Work Environ Health. 2012, 38:163-170. 10.5271 /sjweh.3262

27. Garg R, Cheung JP, Fung BK, Ip WY: Epidemiology of occupational hand injury in Hong Kong. Hong Kong Med J. 2012, 18:131-136.

28. Mostafa N, Sayed A, Osman A: Work-related hand injuries treated at a tertiary care hospital . J Egypt Public Health Assoc. 2014, 89:85-89. 10.1097/01.EPX.0000453132.09162.52 